
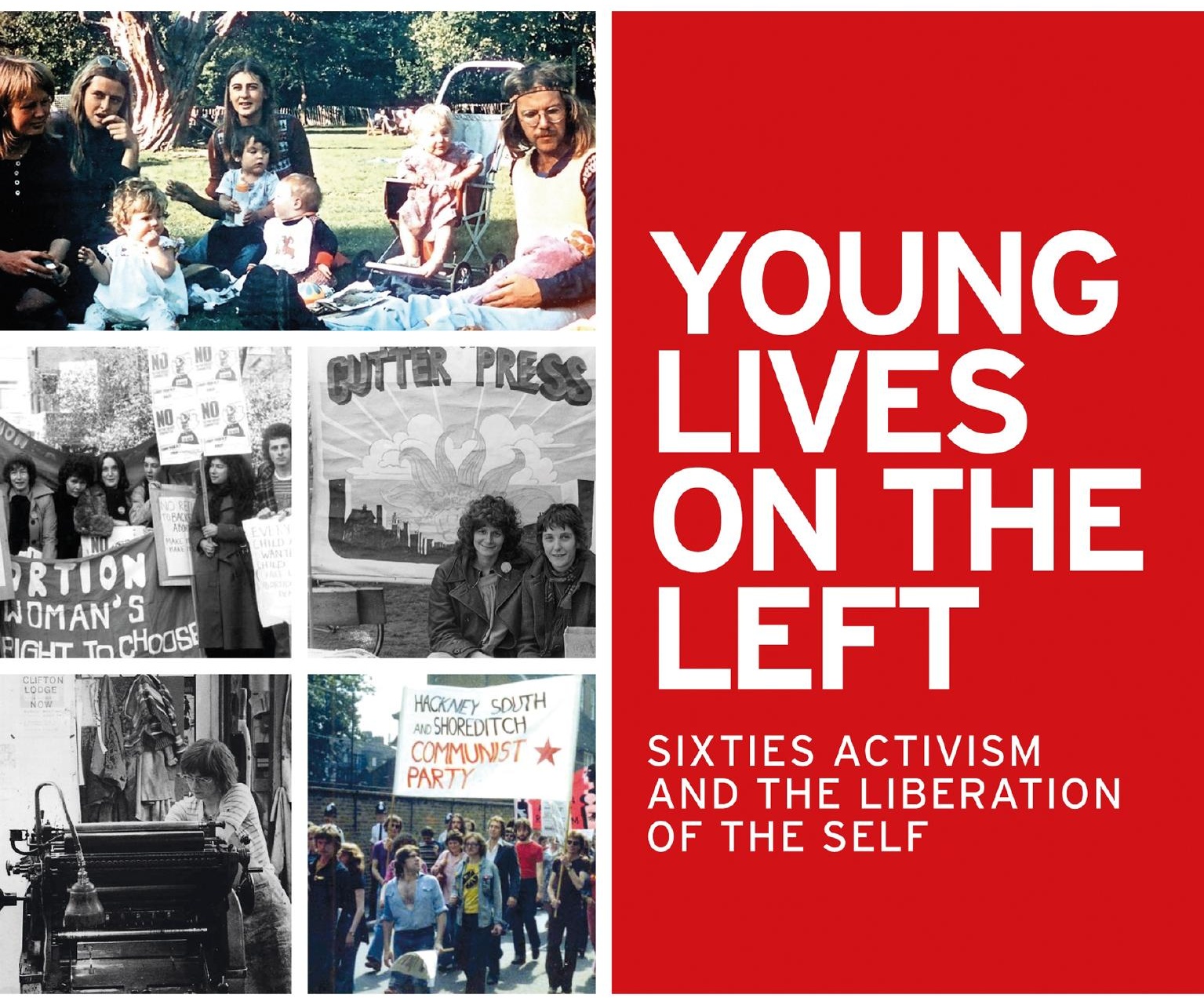

SIXTIES ACTIVISM AND THE LIBERATION OF THE SELF

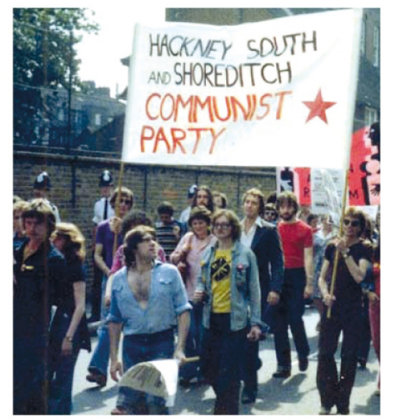

\title{
CELIA HUGHES
}




\section{Young lives on the Left}

\section{MANCHESTER 1824}

Manchester University Press 
Celia Hughes - 9780719098314 Downloaded from manchesterhive.com at 04/26/2023 03:06:56PM via free access 


\title{
Young lives on the Left Sixties activism and the liberation of the self
}

\author{
Celia Hughes
}




\section{Copyright (C) Celia Hughes 2015}

The right of Celia Hughes to be identified as the author of this work has been asserted by her in accordance with the Copyright, Designs and Patents Act 1988.

Published by Manchester University Press

Altrincham Street, Manchester M1 7JA

www.manchesteruniversitypress.co.uk

British Library Cataloguing-in-Publication Data

A catalogue record for this book is available from the British Library

Library of Congress Cataloging-in-Publication Data applied for

ISBN 9780719091940 hardback

First published 2015

The publisher has no responsibility for the persistence or accuracy of URLs for any external or third-party internet websites referred to in this book, and does not guarantee that any content on such websites is, or will remain, accurate or appropriate.

Typeset 10.5/12.5pt Sabon

by Graphicraft Limited, Hong Kong 